\title{
ERRATA
}

\section{Pseudonocardia asaccharolytica sp. nov. and Pseudonocardia sulfidoxydans sp. nov., two new dimethyl disulfide-degrading actinomycetes and emended description of the genus Pseudonocardia}

Katrin Reichert, André Lipski, Silke Pradella, Erko Stackebrandt and Karlheinz Altendorf International Journal of Systematic Bacteriology (1998), 48, 441-449

p. 445, Table 3, column 2 (P. asaccharolytica), row 23 (Dimethyl sulfide) should read ' - ' not ' + '

p. 446, column 2, lines 8 and 9 should read 'The isolates of group I degraded only DMDS ...' not 'The isolates of group I degraded only DMS ...'

\section{Staphylococcus succinus sp. nov., isolated from Dominican amber}

L. H. Lambert, T. Cox, K. Mitchell, R. A. Rosselló-Mora, C. Del Cueto, D. E. Dodge, P. Orkand and R. J. Cano

International Journal of Systematic Bacteriology (1998), 48, 511-518

In this paper it was stated that the cell wall of Staphylococcus succinus contains diaminopimelic acid. Upon reanalysis using an amino acid analyser, the cell wall has been shown to contain lysine and glycine but no diaminopimelic acid.

\section{Entomoplasma freundtii sp. nov., a new species from a green tiger beetle (Coleoptera : Cicindelidae)}

Joseph G. Tully, Robert F. Whitcomb, Kevin J. Hackett, David L. Williamson, Frederic Laigret, Patricia Carle, Joseph M. Bové, Roberta B. Henegar, Nicole M. Ellis, Deborah E. Dodge and Jean Adams

International Journal of Systematic Bacteriology (1998), 48, 1197-1204

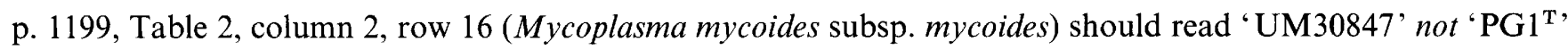

p. 1201, Fig. 3, line 4 should read 'Mycoplasma mycoides subsp. mycoides UM30847' not 'Mycoplasma mycoides subsp. mycoides $\mathrm{PG}^{\mathrm{T}}$, 